\title{
Radiant Floor Heating System
}

\author{
Byung-Cheon Ahn \\ Department of Building Equipment System Engineering, Kyungwon University \\ Korea
}

\section{Introduction}

The radiant floor heating system controls indoor air temperature by heat transfer from heated surface to indoor air, after the heat has been applied into a floor structure mass by using hot water heating coil buried under the floor. In this case, hot water is provided by a boiler, then, conveyed to indoor floor heating coil through pipe network.

The radiant floor heating system can operate transmitting power quietly and efficiently with no noise at low costs of the initial investment and with low maintenance. However, since hot water heating coil is buried under the floor, the system has a defect that it has large thermal inertia by heavy heat capacitance of the floor structure mass. In addition, response characteristics with long time delay will be caused due to certain amount of time needed to heat up the structure mass(Ahn, 2010). Thus, saving energy and maintaining comfortable indoor thermal environment would be possible only if a proper control method is applied into the system, considering its thermal inertia.

This chapter introduces system features and mathematical background of radiant floor heating system. Especially, it covers theoretical background of analysis on heat transfer characteristics in pipes and indoor heat flow characteristics to help understand dynamic characteristics of energy in the system. In addition, explanation is given on types and characteristics of automatic thermostatic valves in the system that supplies hot water with on-off or proportional control, and more information is demonstrated on heat flow characteristics and heating performance of the radiant floor heating system in applying various kinds of control systems to comfort indoor heat and save energy.

\section{Heat transfer in pipes}

In case of radiant floor heating system, hot water from the boiler will be streamed into households through pipes, and these pipes can be distinguished into two types; outdoor exposed pipe covered with heat insulator, and pipe buried under the floor structure mass. Thus, separate mathematical analyzing method is suggested to explain two types of pipes. Firstly, fig. 1 depicts pipe covered with heat insulator. In this case, the pipe has exposed outdoor structure and constant outdoor temperature. Assuming that there is no superheating or subcooling of the fluid that changes phase, and its pressure does not change, the LMTD(Log Mean Temperature Difference) applies and in combination with a heat balance(Stoecker, 1980) gives

$$
q=U A \frac{\left(T_{a o}-T_{i}\right)-\left(T_{a o}-T_{o}\right)}{\ln \left[\left(T_{a o}-T_{i}\right) /\left(T_{a o}-T_{o}\right)\right]}=\rho W C_{p}\left(T_{o}-T_{i}\right)
$$


where,

q Heat transfer

U Heat transfer coefficient

$\rho \quad$ Water density

$\mathrm{C}_{\mathrm{p}} \quad$ Specific heat

$\mathrm{V} \quad$ Flow velocity

$\mathrm{T}_{\mathrm{i}}, \mathrm{T}_{\mathrm{o}} \quad$ Inlet and outlet temperature

$\mathrm{T}_{\mathrm{ao}} \quad$ Ambient temperature

W Flow rate $\left(n R_{1}^{2} \cdot \mathrm{V}\right)$

A Outside surface area of pipe $\left(2 \pi R_{1} L\right)$

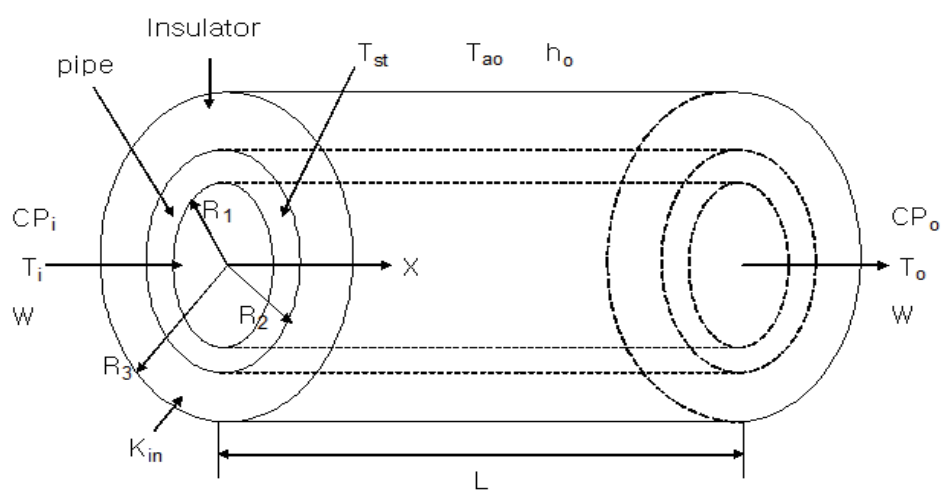

Fig. 1. Insulated pipe

Therefore, $T_{0}$, outlet temperature of the pipe, can be indicated from the formula (2)

$$
T_{o}=T_{i}+\left(T_{a o}-T_{i}\right) \cdot\left[1-\exp \left(-\frac{-U A}{\rho W C_{p}}\right)\right]
$$

$T_{L}$, average temperature of hot water considering the length of pipe, can be found as

$$
T_{L}=\frac{1}{L} \int_{0}^{L} T_{x} d x=T_{i}+\left(T_{a o}-T_{i}\right) \cdot[1+(\exp (-E)-1) / E]
$$

Where $\mathrm{E}=\mathrm{UA} / \rho W C_{\mathrm{p}}$, and equivalent heat transfer coefficient, $\mathrm{U}$, between fluid flow and outdoor is

$$
U=\frac{1}{\frac{1}{h_{i}}+\frac{R_{1}}{K_{s t}}+\ln \left(\frac{R_{2}}{R_{1}}\right)+\frac{R_{1}}{K_{i n}} \ln \left(\frac{R_{3}}{R_{2}}\right)+\frac{R_{1}}{R_{2} h_{o}}}
$$

Where,

$\mathrm{K}_{\text {st }}$

Thermal conductivity of pipe

$\mathrm{K}_{\text {in, }}$

Thermal conductivity of insulator

$\mathrm{R}_{1}$ and $\mathrm{R}_{2}$

Inside and outside diameter of pipe

$\mathrm{R}_{3}$

Outside diameter of insulator

The heat transfer coefficient of hot water inside the pipe, $\left(h_{i}\right)$, is 


$$
\begin{gathered}
\mathrm{h}_{\mathrm{i}}=0.023 \cdot \operatorname{Re}^{0.8} \operatorname{Pr}^{0.3} \cdot \frac{\mathrm{k}_{\mathrm{w}}}{\mathrm{D}_{\mathrm{i}}} \quad(\operatorname{Red}>2300) \\
h_{i}=4.36 \cdot \frac{k_{w}}{D_{i}} \quad(\operatorname{Red} \leq 2300)
\end{gathered}
$$

Where Re is Reynolds number $\left(\mathrm{V} \cdot \mathrm{D}_{\mathrm{i}} / \mathrm{v}\right)$ and Pr is Prantl number $(\mathrm{v} / \alpha)$. Also, heat transfer coefficient of exterior of the pipe, $\left(h_{o}\right)$, is

$$
h_{o}=\frac{k_{f} \cdot N_{\mu D}}{D_{o}}
$$

Where $\mathrm{k}_{\mathrm{f}}$ is thermal conductivity of air.

Nusselt number $\left(\mathrm{Nu}_{\mathrm{D}}\right)$ can be solved differently regarding horizontal pipe and vertical pipe (Holman, 1981).

In case of horizontal pipe,

$$
\begin{gathered}
N_{\mu D}=0.53\left(G r_{D} \cdot P r_{f}\right)^{\frac{1}{4}}\left(10^{4} \leq G r_{D} \cdot P r_{f} \leq 10^{9}\right) \\
N_{\mu D}=0.13\left(G r_{D} \cdot P r_{f}\right)^{\frac{1}{3}}\left(10^{9} \leq G r_{D} \cdot P r_{f} \leq 10^{12}\right)
\end{gathered}
$$

And in case of vertical pipe,

$$
\begin{aligned}
& N_{\mu D}=0.59\left(G r_{D} \cdot P r_{f}\right)^{\frac{1}{4}}\left(10^{4} \leq G r_{D} \cdot P r_{f} \leq 10^{9}\right) \\
& N_{\mu D}=0.1\left(G r_{D} \cdot P r_{f}\right)^{\frac{1}{3}}\left(10^{9} \leq G r_{D} \cdot P r_{f} \leq 10^{13}\right)
\end{aligned}
$$

Where $\operatorname{Pr}_{\mathrm{f}}$ is Prantl number for air and $\mathrm{Gr}_{\mathrm{D}}$ is Grashof number.

Considering outdoor temperature $\left(\mathrm{T}_{\mathrm{ao}}\right)$, and temperature difference $(\Delta \mathrm{T})$ between outdoor and pipe's external surface, Grashof number can be expressed as below.

$$
G r_{D}=\frac{g \cdot \beta \cdot \Delta T \cdot D_{o}{ }^{3}}{v_{f}{ }^{2}}=\frac{g \cdot \Delta T \cdot D_{o}{ }^{3}}{v_{f}{ }^{2} \cdot T_{a o}}
$$

$\Delta \mathrm{T}$ value is needed in order to figure out heat transfer coefficient, $\mathrm{h}_{\mathrm{o}}$, while $\mathrm{U}$ value must be solved to find $\Delta \mathrm{T}$. Thus, accurate value, $\Delta \mathrm{T}$, can be measured through repeated calculation, assuming $\Delta \mathrm{T}$ as a proper number.

Concerning that structure of hot water heating coil pipe is buried under the floor in radiant floor heating system in general, heat transfer phenomena from hot water pipe to floor and ceiling surface must be reviewed. Fig. 2 is a diagram of pipe buried under the household floor. Considering thermal behavior from hot water through pipe gives the following. Very small volume $(A \cdot d x)$ of the amount of heat in the hot water $(\Delta q)$ can be formulated:

$$
\Delta q=\rho \cdot A \cdot d x \cdot C_{p} \cdot T_{x}
$$

where,

$\begin{array}{ll}\rho & \text { Water density } \\ A & \text { Cross sectional area of the pipe } \\ C_{p} & \text { Specific heat of hot water }\end{array}$


$\mathrm{T}_{\mathrm{x}} \quad$ Temperature of hot water

Hot water in a very small volume has a heat transfer loss after a very short time as follows.

$$
d \Delta q=-\rho \cdot A \cdot d x \cdot C_{p} \cdot d T_{x}
$$

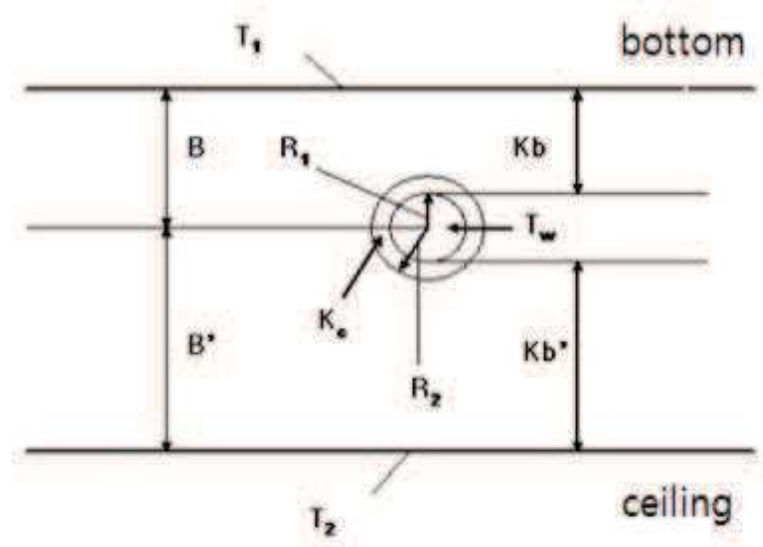

Fig. 2. Pipe buried in semi-infinite medium having isothermal surface

This value is a sum of the heat amounts emitting to the room floor ( $d \Delta \mathrm{qb})$ and to the ceiling surface of the room below $(\mathrm{d} \Delta \mathrm{qc})$.

This occurs because an amount of heat from the heated water is transferred to the floor and ceiling surface below.

$$
d \Delta q=d \Delta q_{b}+d \Delta q_{C}
$$

Where

$\mathrm{d} \Delta \mathrm{q}_{\mathrm{b}}=\mathrm{U}_{1} \cdot \mathrm{A}_{\mathrm{p}} \cdot\left(\mathrm{T}_{\mathrm{k}}-\mathrm{T}_{1}\right) \cdot \mathrm{dx} \cdot \mathrm{dt}$

$\mathrm{d} \Delta \mathrm{q}_{\mathrm{c}}=\mathrm{U}_{2} \cdot A_{\mathrm{p}} \cdot\left(\mathrm{T}_{\mathrm{k}}-\mathrm{T}_{2}\right) \cdot \mathrm{dx} \cdot \mathrm{dt}$

$$
\begin{aligned}
& \mathrm{U}_{1}=\frac{1}{\frac{1}{\mathrm{~h}_{\mathrm{i}}}+\frac{\mathrm{R}_{1} \ln \left(\mathrm{R}_{2} / \mathrm{R}_{1}\right)}{\mathrm{K}_{\mathrm{c}}}+\frac{\mathrm{R}_{1} \cosh ^{-1}\left(\mathrm{~B} / \mathrm{R}_{2}\right)}{\mathrm{K}_{\mathrm{b}}}} \\
& \mathrm{U}_{1}=\frac{1}{\frac{1}{\mathrm{~h}_{\mathrm{i}}}+\frac{\mathrm{R}_{1} \ln \left(\mathrm{R}_{2} / \mathrm{R}_{1}\right)}{\mathrm{K}_{\mathrm{c}}}+\frac{\mathrm{R}_{1} \cosh ^{-1}\left(\mathrm{~B}^{\prime} / \mathrm{R}_{2}\right)}{\mathrm{K}_{\mathrm{b}^{\prime}}}}
\end{aligned}
$$

where,

$\mathrm{U}_{1} \quad$ Heat transfer coefficient from pipe surface to the floor surface

$\mathrm{U}_{2} \quad$ Heat transfer coefficient from pipe surface to the ceiling surface of the bottom layer

$h_{i} \quad$ Heat transfer coefficient of pipe inner surface

$\mathrm{T}_{1} \quad$ Floor surface temperature

$\mathrm{T}_{2} \quad$ Ceiling surface temperature of the bottom layer

$\mathrm{K}_{\mathrm{p}} \quad$ Thermal conductivity of pipe

$\mathrm{K}_{\mathrm{b}} \quad$ Equivalent thermal conductivity from pipe surface to the floor surface 
$\mathrm{K}_{\mathrm{b}}{ }^{\prime} \quad$ Equivalent thermal conductivity from pipe surface to the ceiling surface of the bottom layer

B Distance from the middle of pipe to the floor surface

B' Distance from the middle of pipe to the ceiling surface of the bottom layer

$\mathrm{A}_{\mathrm{p}} \quad$ Girth of pipe

$\mathrm{R}_{1} \quad$ Inside radius of pipe

$\mathrm{R}_{2} \quad$ Outside radius of pipe

After substituting equation (15) for equation (14), categorized according to hot water temperature, assuming that $\mathrm{T}_{1}$ and $\mathrm{T}_{2}$ are steady for a very short time $(\mathrm{dt})$, and integrating for pipe length, the outlet temperature of hot water for length $\mathrm{L}$ can be expressed as the following equation (16) for hot water inlet temperature

$$
T_{O}=\frac{U_{1} T_{1}+U_{2} T_{2}}{U_{1}+U_{2}}+\left(T_{i}-\frac{U_{1} T_{1}+U_{2} T_{2}}{U_{1}+U_{2}}\right) \exp \left(-\frac{\left(U_{1}+U_{2}\right) \cdot A_{p} \cdot L}{\rho \cdot A \cdot C_{p} \cdot v}\right)
$$

where,

$\mathrm{T}_{\mathrm{o}} \quad$ Hot water temperature of pipe outlet

$\mathrm{T}_{\mathrm{i}} \quad$ Hot water temperature of pipe inlet

L The length of pipe

$\mathrm{v} \quad$ Mean flow velocity $(\mathrm{dx} / \mathrm{dt})$

If we replace $T_{o}$ with $T_{x}$ and $\mathrm{L}$ with $\mathrm{x}$, then integrate this for an entire length, the mean temperature of hot water could be achieved as in the following equation (17)

$$
T_{W}=\frac{1}{L} \int_{0}^{L} T_{X} d x=\frac{U_{1} T_{1}+U_{2} T_{2}}{U_{1}+U_{2}}+\left(T_{i}-\frac{U_{1} T_{1}+U_{2} T_{2}}{U_{1}+T_{2}}\right)\left(\frac{1-e^{-D L}}{D L}\right)
$$

Where $\quad D=\frac{\left(U_{1}+U_{2}\right) \cdot A_{1}}{\rho \cdot A \cdot C_{P} \cdot V}$

Fig. 3 depicts pipe network buried in a house of apartment building. Hot water is supplied from supply header through 5 distinguished pipes separately. Average temperature of each room can be found using formula (17)

\section{Indoor heat transfer}

Figure 4 shows heat amounts and temperatures of each part of the room; floor, ceiling, wall and window. There are 3 routes for heat transfer; conduction in the floor, ceiling and wall, convection with indoor air and radiant heat transfer between the heated floor and ceiling surface, and a non-heated wall in the house.

The amount of thermal conduction (q1) from the heated water in the pipe to the floor surface, and the convective amount (q2) from the floor to the indoor air can be shown as equation (18), (19).

$$
\begin{gathered}
q_{1}=\frac{A_{p}\left(T_{W} T_{1}\right) \cdot L}{\frac{1}{h_{i}}+\frac{R_{1} l n\left(R_{2} / R_{1}\right)}{K_{c}}+\frac{R_{1} \cosh h^{-1}\left(B / R_{2}\right)}{K_{b}}} \\
q_{2}=\frac{2.41 \cdot A_{1}\left(T_{1}-T_{a}\right)^{1.31}}{D e^{0.08}}
\end{gathered}
$$

Where $T_{a}$ is the temperature of indoor air and $D_{e}$ is the equivalent diameter of floor slab. 


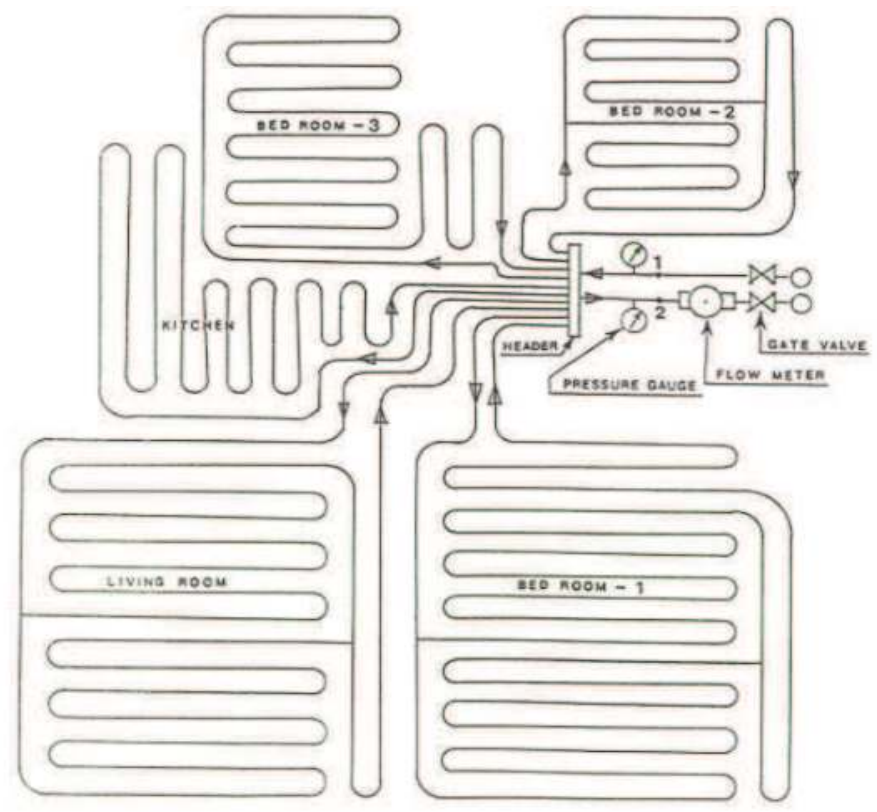

Fig. 3. Pipe network buried in a house of apartment building

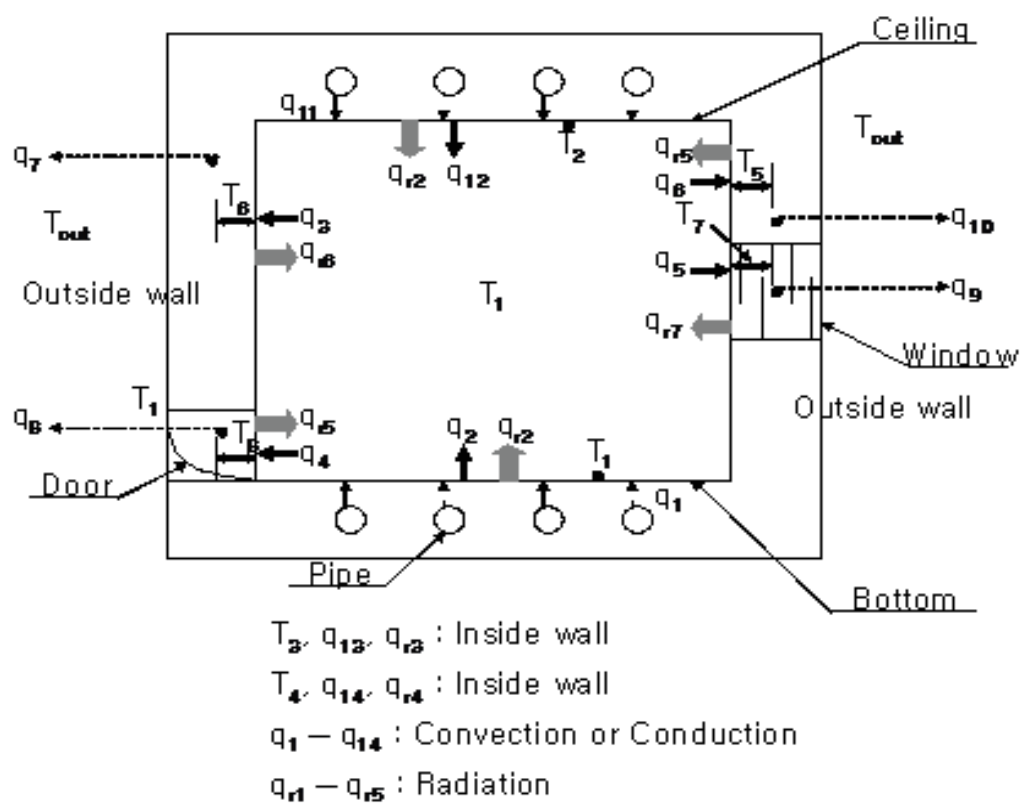

Fig. 4. Schematic diagram for heat flow for the heat transfer analysis in the room 
The amount of the thermal convection to wall, window, and door surrounding indoor air(ASHRAE, 2004)

$$
q_{n}=\frac{1.87 \cdot A_{k}\left(T_{a}-T_{k}\right)^{1.32}}{H_{k}^{0.05}}
$$

Where $\mathrm{H}$ is indoor wall height.

The amount of thermal conduction (q11) from hot water pipe buried under the floor of upper level can be shown as equation (21).

$$
q_{11}=\frac{A_{p}\left(T_{w}-T_{2}\right) \cdot L}{\frac{1}{h_{i}}+\frac{R_{1} \ln \left(\frac{R_{2}}{R_{1}}\right)}{K_{c}}+\frac{R_{1} \cos ^{-1}\left(\frac{B^{\prime}}{R_{2}}\right)}{K_{b^{\prime}}}}
$$

In addition, the amount of radiant heat transfer $\left(q_{r k}\right)$ in each surface is calculated with the Gebhart's enclosure analysis method(Segel, 1981) as in the following equation (22).

$$
\begin{gathered}
q_{r k}=A_{k} \cdot \varepsilon_{k} \cdot \sigma \cdot T_{k}^{4}-\sum_{j=1}^{n} A_{j} \cdot \varepsilon_{j} \cdot \sigma \cdot T_{j}^{4} \cdot G_{j k} \\
G_{j k}=F_{j-k} \cdot \varepsilon_{k}+F_{j-k} \cdot \rho_{1} \cdot G_{1 k}+\cdots+F_{j-n} \cdot \rho_{n} \cdot G_{n k} \quad(j=1,2, \cdots, n)
\end{gathered}
$$

where,

$\mathrm{q}_{\mathrm{rk}} \quad$ Radiant heat transfer for $\mathrm{k}_{\mathrm{th}}$ surface

$\mathrm{A}_{\mathrm{k}} \quad \mathrm{k}_{\mathrm{th}}$ surface area

$\varepsilon_{\mathrm{k}} \quad \mathrm{k}_{\text {th }}$ surface emissivity

$\sigma \quad$ boltzmann constant

$\mathrm{T}_{\mathrm{k}} \quad \mathrm{k}_{\mathrm{th}}$ surface temperature

$\rho_{1-n} \quad$ Reflectivity of surface

$\mathrm{F}_{\mathrm{j}-\mathrm{k}} \quad$ Coefficient of form between the inside and outside surface

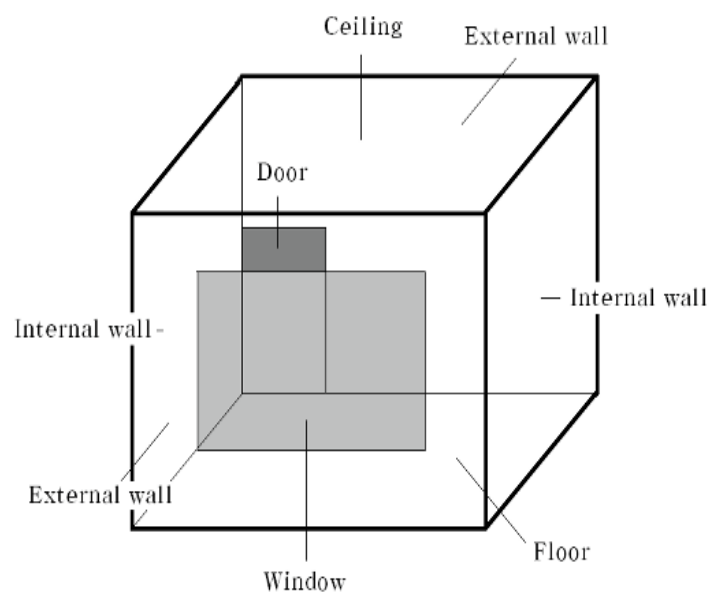

Fig. 5. Schematic of room for radiation heat transfer analysis 
Temperatures of indoor air and each part of the room can be determined by an analysis of these 3 heat transfers: conduction, convection and radiation. In this study, each temperature is measured using the electrical resistance-capacitance circuit method(Sepsy, 1972) as shown in Fig. 6. It is based on assumptions that heat capacity for each wall is concentrated to one point in the wall, and that the temperature from the point to the wall surface is steady. Equivalent heat resistances of either side from each central node in the wall are the same by selecting the point. Heat loss to outdoor air is considered by setting the new central node(Chang, 1996), which is the point at which both equivalent heat resistances of the existing node and the surface are the same energy equation of each point is as follows

$$
\begin{gathered}
C_{a} \frac{d T_{a}}{d t}=q_{2}-q_{3}-q_{4}-q_{5}-q_{6}-q_{12 c}-q_{13}-q_{14} \\
C_{p} \frac{d T_{p}}{d t}=\sum q_{\text {in }}-\sum q_{\text {out }}-q_{r k}
\end{gathered}
$$

where,

$\mathrm{C}_{\mathrm{p}} \quad$ Capacitance of each part

$\mathrm{T}_{\mathrm{p}} \quad$ Temperature of each part

$\mathrm{q}_{\text {in, }} \mathrm{q}_{\text {out }}$ Heat transfer by convection or conduction

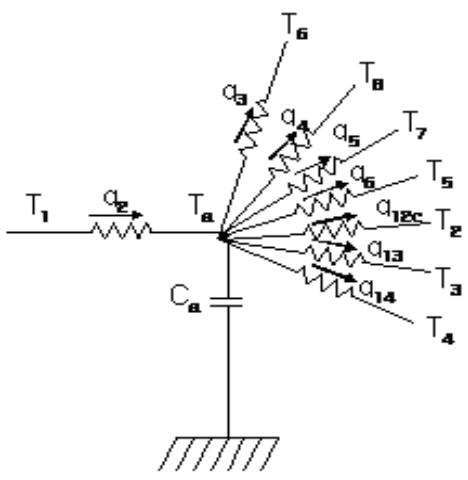

(a)

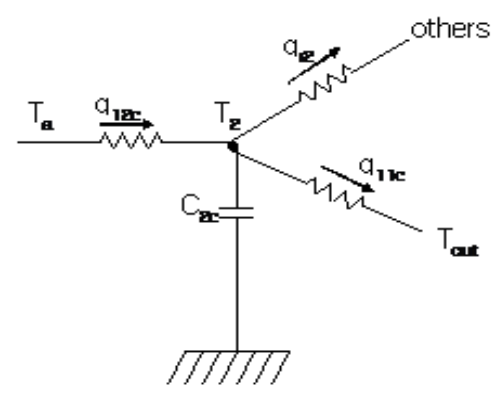

(b)

Fig. 6. An equivalent R-C circuit for unsteady energy analysis

\section{Automatic thermostatic valves}

In case of radiant floor heating system, automatic temperature control valve is used in order to consume energy effectively and maintain pleasant indoor temperature. This valve has similar function as those of gate or glove valve, but it can be separated into electric powered type and non-electric powered type in terms of the source of power that moves valve disk. Electric powered type uses external force such as electricity, while non-electric powered type uses only internal driving element such as shape memory alloy and spring. In general, electric powered type operates by motors is composed of room temperature controller and automatic thermostatic valve, and non-electric powered type only consists of automatic thermostatic valve. 
Furthermore, Automatic thermostatic valve itself can be differed into on-off type and proportional control type in terms of control method. Fig. 7 shows control method of automatic thermostatic valve expressed with flux supply method from temperature change.
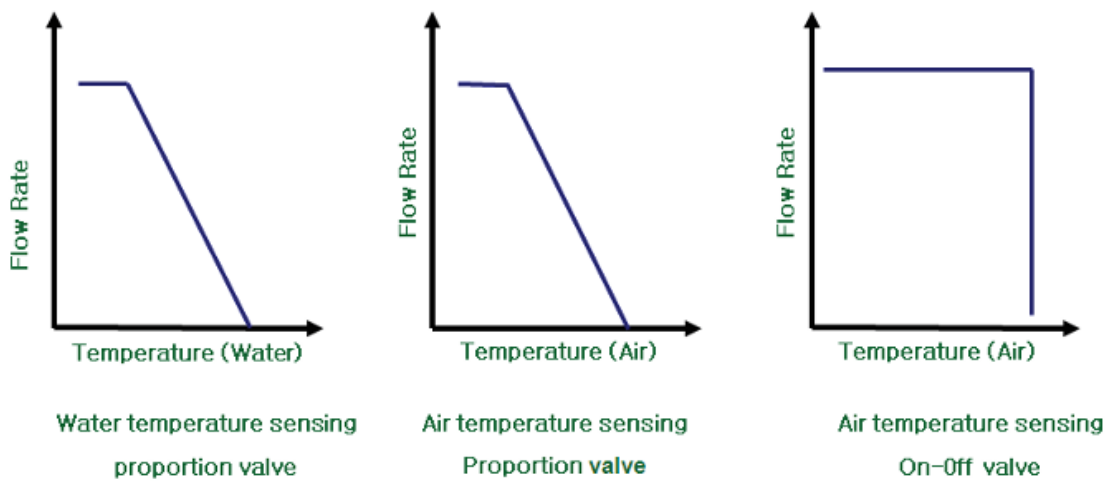

Fig. 7. Characteristics of Flow rates vs temperature in control methods of automatic thermostatic valves

Fig. 8 contains types of heating automatic thermostatic valve, and table 1 is about the characteristics of each type of valves.

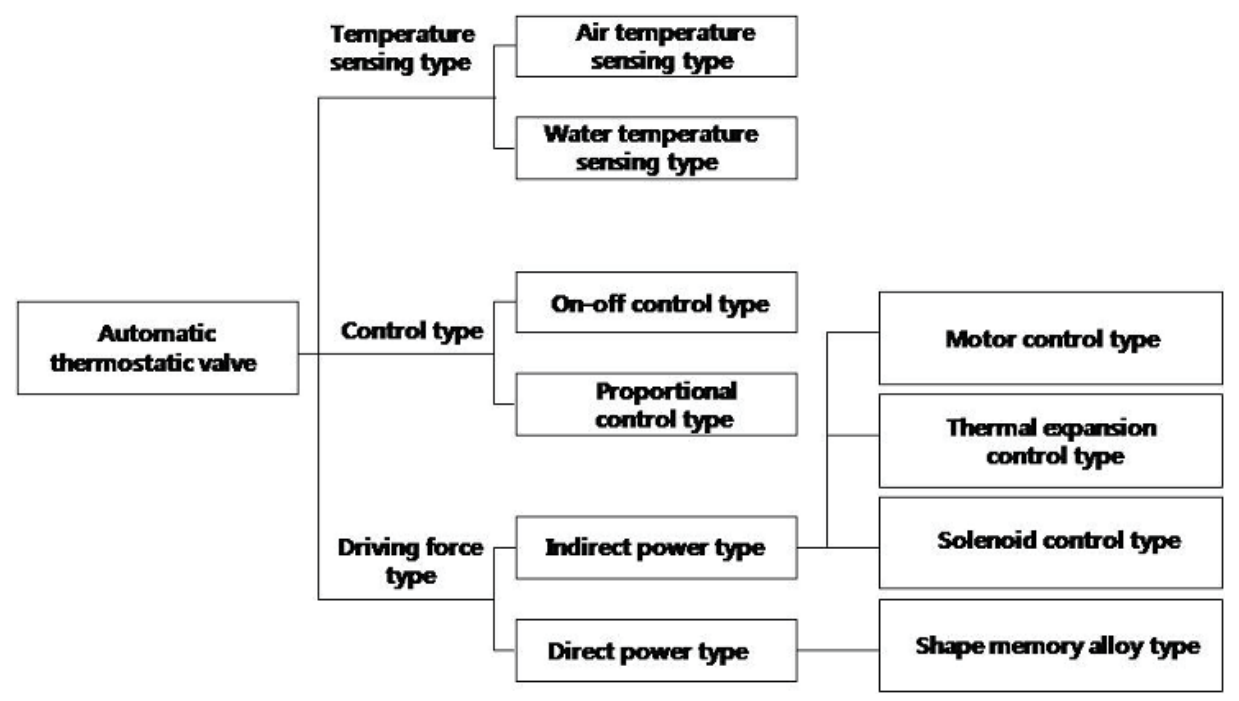

Fig. 8. Various classifications for automatic thermostatic valves

First, in case of electric powered automatic thermostatic valve, control part senses indoor air temperature of each room and transmits signal to driving part (thermostatic valve) to control the amount of heating hot water flowing through the pipe. Temperature sensor called thermister is mostly used to sense temperature from indoor temperature controller, and it is thermally sensitive semiconductor resistance thermometer. Thermister is widely 
used as temperature sensor for household electric appliances and industrial machineries, since its temperature usage range is $-50 \sim 500^{\circ} \mathrm{C}$, which can be applied to every possible range that ordinary temperature control is needed, and it is not only cheap and tiny but highly sensitive. Driving part of electric powered type automatic thermostatic valve can be separated into 3 different methods using ball valve, cone valve, and solenoid. Solenoid valve has 2 seconds of on-off response time, while ball valve has 10 seconds and cone valve has several ten seconds to minutes

Non-electric powered type automatic thermostatic valve using shape memory alloy actively controls on-off state of valve by sensing shape memory alloy element; closes valve proportional to temperature due to the increase of returning water temperature, and opens valve by returning spring due to decrease of returning water temperature.

As a merit, power supply is not necessary and response time is faster than thermal expansion. Also, structure only consisting of thermal static valve is very simple and endurance is superior, because Ti-Ni shape alloy spring is used as an operational element.

However, it has a demerit that it has to passively decide flux amount that fits to hot water temperature amount considering consumer's thermal surroundings after construction. Also, it is significant to choose appropriate controlling components for types and characteristics of installing heating system.

\begin{tabular}{|c|c|c|c|c|c|}
\hline & \multicolumn{3}{|c|}{ Indirect power type } & \multicolumn{2}{|l|}{ Direct type } \\
\hline & $\begin{array}{l}\text { Motor control } \\
\text { type }\end{array}$ & \begin{tabular}{|l|}
$\begin{array}{l}\text { Solenoid } \\
\text { control } \\
\text { type }\end{array}$ \\
\end{tabular} & $\begin{array}{l}\text { Thermal } \\
\text { expansional } \\
\text { control type }\end{array}$ & $\begin{array}{l}\text { Shape memory } \\
\text { alloy type }\end{array}$ & $\begin{array}{l}\text { Capillary tube } \\
\text { Type }\end{array}$ \\
\hline $\begin{array}{l}\text { Control } \\
\text { method }\end{array}$ & $\begin{array}{l}\text { - Temperature } \\
\text { sensing type } \\
\text { - On-off type }\end{array}$ & $\begin{array}{l}\text { - Temperature } \\
\text { sensing type } \\
\text { - On-off type }\end{array}$ & $\begin{array}{l}\text { - Temperature } \\
\text { sensing type } \\
\text { - On-off type }\end{array}$ & $\begin{array}{l}\text { - water } \\
\text { temperature } \\
\text { sensing type } \\
\text { - Proportional } \\
\text { control type } \\
\end{array}$ & $\begin{array}{l}\text { - Water } \\
\text { temperature } \\
\text { sensing type } \\
\text { - Proportional } \\
\text { control type } \\
\end{array}$ \\
\hline $\begin{array}{l}\text { Operating } \\
\text { source }\end{array}$ & Electric motor & Electromagnet & $\begin{array}{l}\text { Liquid thermal } \\
\text { expansion }\end{array}$ & $\begin{array}{l}\text { Shape memory } \\
\text { alloy spring }\end{array}$ & $\begin{array}{l}\text { Liquid thermal } \\
\text { expansion } \\
\text { bellows }\end{array}$ \\
\hline $\begin{array}{l}\text { Response } \\
\text { time }\end{array}$ & $\begin{array}{l}\text { Within several } \\
\text { ten seconds }\end{array}$ & $\begin{array}{l}\text { Within several } \\
\text { seconds }\end{array}$ & $\begin{array}{l}\text { Within several } \\
\text { minutes }\end{array}$ & $\begin{array}{l}\text { Within several } \\
\text { seconds }\end{array}$ & $\begin{array}{l}\text { Within several } \\
\text { ten minutes }\end{array}$ \\
\hline Merit & $\begin{array}{l}\text { - Fast response } \\
\text { - Easy } \\
\text { installation }\end{array}$ & $\begin{array}{l}\text { - Fastest } \\
\text { response } \\
\text { - Simple } \\
\text { Structure } \\
\text { - Low cost } \\
\end{array}$ & & $\begin{array}{l}\text { - Electric power } \\
\text { isnecessary } \\
\text { - Good endurance } \\
\text { - Proportional } \\
\text { type }\end{array}$ & $\begin{array}{l}\text { - Electric power } \\
\text { is unnecessary } \\
\text { - Proportional } \\
\text { Type }\end{array}$ \\
\hline Demerit & $\begin{array}{l}\text {-Electric power } \\
\text { is necessary } \\
\text { - High cost }\end{array}$ & $\begin{array}{l}\text { - High } \\
\text { pressure loss }\end{array}$ & $\begin{array}{l}\text { Relatively slow } \\
\text { response }\end{array}$ & $\begin{array}{l}\text { Manual valve } \\
\text { Setting }\end{array}$ & $\begin{array}{l}\text {-Liquid quality } \\
\text { variation } \\
\text {-Difficult } \\
\text { installation }\end{array}$ \\
\hline
\end{tabular}

Table 1. Characteristics of classified automatic thermostatic valves

\section{Heating control system performance analysis}

If indoor temperature were controlled by applying automatic thermostatic valve for radiant floor heating system, response characteristics of long time delay on control response would 
occur due to large heat capacitance of floor structure mass. In order to examine response characteristics of radiant floor heating system, simulation was performed and was compared and verified with experiment results by using mathematical analysis model of a radiant floor heating system explained in previous $2^{\text {nd }}, 3^{\text {rd }}$ paragraphs.

Fig. 9 shows the results of the experiment and simulation (Ahn, 2010).

We measured temperature changes for 5 hours natural cooling after supplying hot-water for 3 hours. For the floor temperature, two temperatures (one at the nearest part to the pipe and the other between the pipes), were measured and compared with temperatures from the simulation data. The chiller to maintain temperature of artificial chamber in the test house was set up to maintain an outdoor air temperature of $8^{\circ} \mathrm{C}$. The reason for cooling is to secure the constant temperature around the room for the indoor heating test.

Data obtained from the entering supply and outdoor temperatures into the simulation for operation, were contrasted to the experimental data.

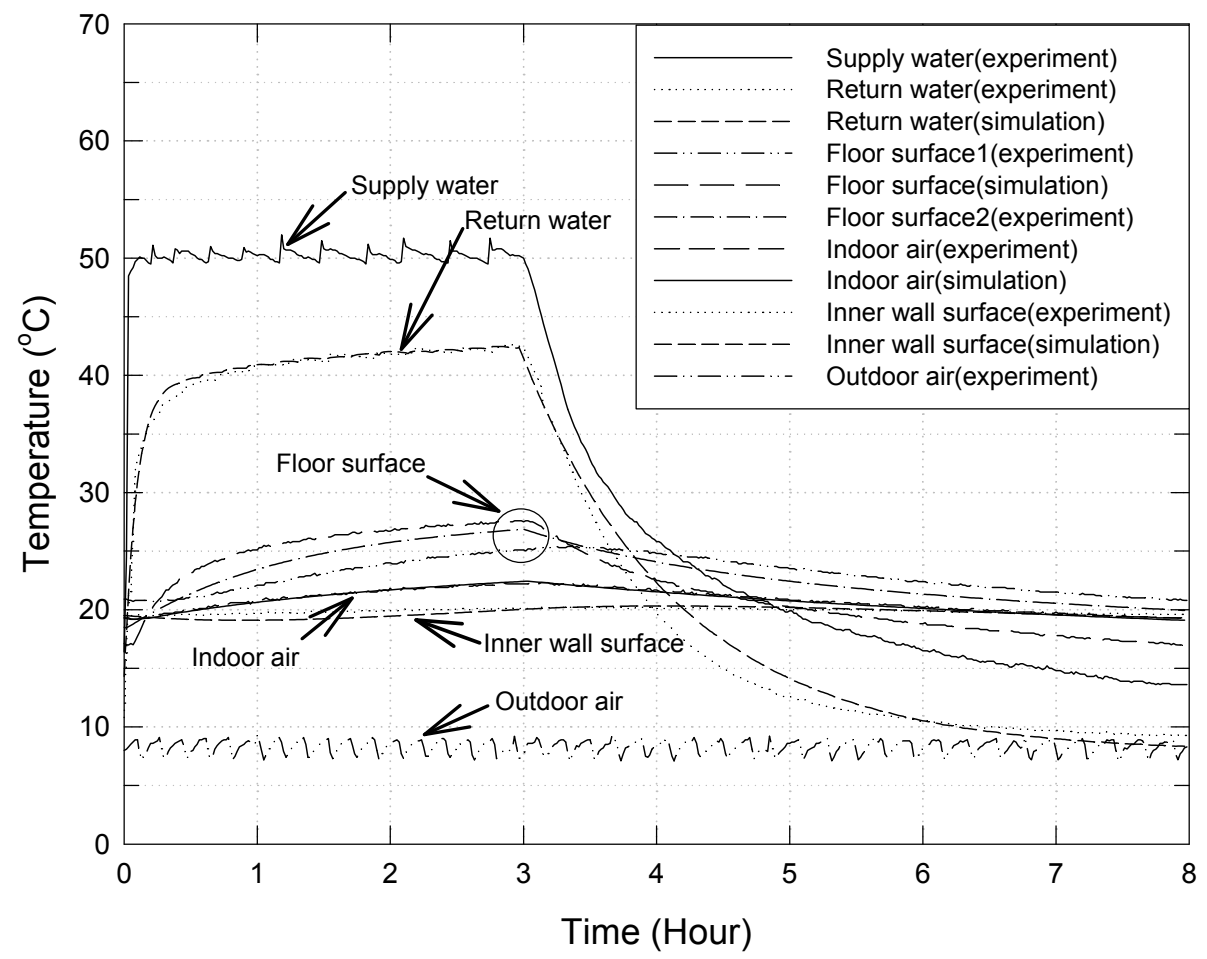

Fig. 9. Comparison of the simulation and experimental data (supply water temperature: $50^{\circ} \mathrm{C}$, flow rate: $0.05 \mathrm{~L} / \mathrm{s}$, outdoor temperature: $8^{\circ} \mathrm{C}$ )

Results showed that the simulation data agreed well with experimental data. Response characteristics will be examined through using simulation model of radiant floor heating system and applying various kinds of automatic thermostatic valves.

First of all, In terms of proportional control and On-Off control, which are types of automatic thermostatic valves, each is classified according to sensing methods; water 
temperature sensing and air temperature sensing. They are performed by testing simulation and defining their features.

Each control of each flow rate and temperature has its own peculiarities as outdoor air changes from the daily lowest temperature $-5^{\circ} \mathrm{C}$ to the highest temperature $5^{\circ} \mathrm{C}$ over 24hours. Table 2 summarizes control characteristics for each of the four studied cases. For the 4 controls: Case 1 does not adjust the flow rate, Case 2 controls the flow rate in proportion to the difference between room temperature and setting point. Case 3 adjusts the flow rate in proportion to the difference between returned-water temperature and setting point, and Case 4 controls the On-off for the supply water by the differential gap according to the difference between the room temperature and setting point.

\begin{tabular}{ll}
\hline Classification & Description \\
\hline Case1 & No control method \\
Case2 & Proportional valve control with air temperature feedback \\
Case3 & Proportional valve control with water temperature feedback \\
Case4 & On-off valve control with air temperature feedback \\
\hline
\end{tabular}

Table 2. Classification of control methods

Fig. 10 summarizes the results of changes in temperatures of return water, the floor and indoor air over 24 hours. The outdoor air is vibratory from $-5^{\circ} \mathrm{C}$ to $5^{\circ} \mathrm{C}$, the return water increases to $43.3^{\circ} \mathrm{C}$ from the set point, and the floor and the indoor air rapidly increases to $20^{\circ} \mathrm{C}$ for 3hours, and then steadily to $32^{\circ} \mathrm{C}$ and then decreases to $27.5^{\circ} \mathrm{C}$. At this time, the mean temperatures of return water and indoor air are $42.3^{\circ} \mathrm{C}$ and $24.9^{\circ} \mathrm{C}$, respectively.

Fig. 11 shows the temperature responses and a flow rate for 24 hours as a result of the proportional control for the indoor air temperature (Case 2) designated from $22.3^{\circ} \mathrm{C}$ to $23.3^{\circ} \mathrm{C}$ to maintain $22.8^{\circ} \mathrm{C}$, the mean indoor temperature. The maximum flow rate helps adjust flow and maintain an indoor air temperature of $23^{\circ} \mathrm{C}$ before reaching the lower limit of $22.3^{\circ} \mathrm{C}$. Controlling flow can offset the change of outdoor air temperature so that indoor air temperature can be maintained.

With the exception of the first stage, the temperature of the return water shows a gentle slope, increasing, and that of floor surface is $27.9^{\circ} \mathrm{C}$ continuously. In this case, each mean temperature of return water and indoor air is $31.8^{\circ} \mathrm{C}$, and $22.8^{\circ} \mathrm{C}$. This air-temperature proportional control maintains indoor temperature through light control regardless of changes in outdoor air temperature.

Fig. 12 shows temperature responses and a flow rate for 24hours as a result of the proportional control for return water temperature (Case 3) designated from $30.5^{\circ} \mathrm{C}$ to $34.5^{\circ} \mathrm{C}$ to maintain $22.8^{\circ} \mathrm{C}$, the mean indoor temperature. The indoor air maintains a temperature of $33.1^{\circ} \mathrm{C}$ after initially increasing to $24.1^{\circ} \mathrm{C}$. The flow rate steadily decreases but its drop dwindles except for the first stage. In this case, the mean temperatures of return water and indoor air are $33^{\circ} \mathrm{C}$, and $22.8^{\circ} \mathrm{C}$, respectively.

Water proportional control does not cope with changes in indoor air temperature, but maintains return water temperature, and if the indoor air temperature were at the best condition, it would be difficult to find an upper and lower limit that can maintain it. 


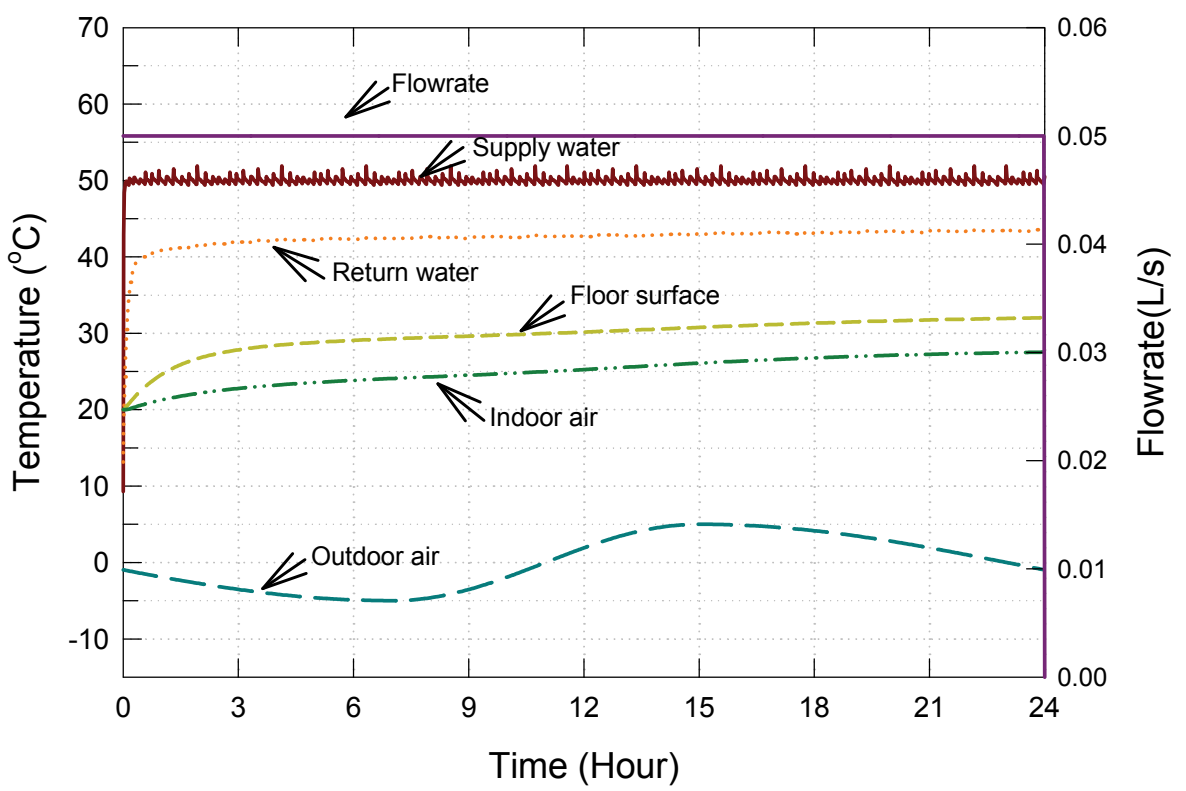

Fig. 10. Various temperature responses for outdoor temperature change with no control (Case 1)

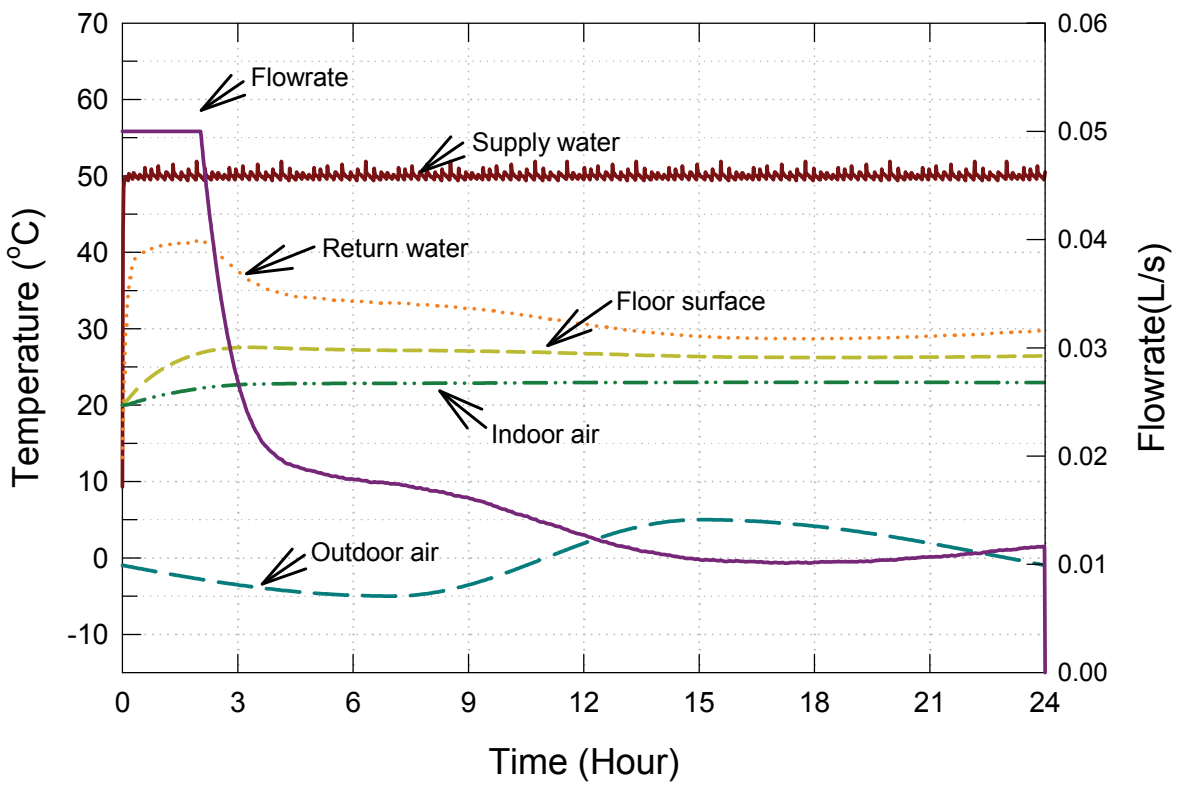

Fig. 11. Various temperature responses with proportional valve control with air temperature feedback (Case 2) 


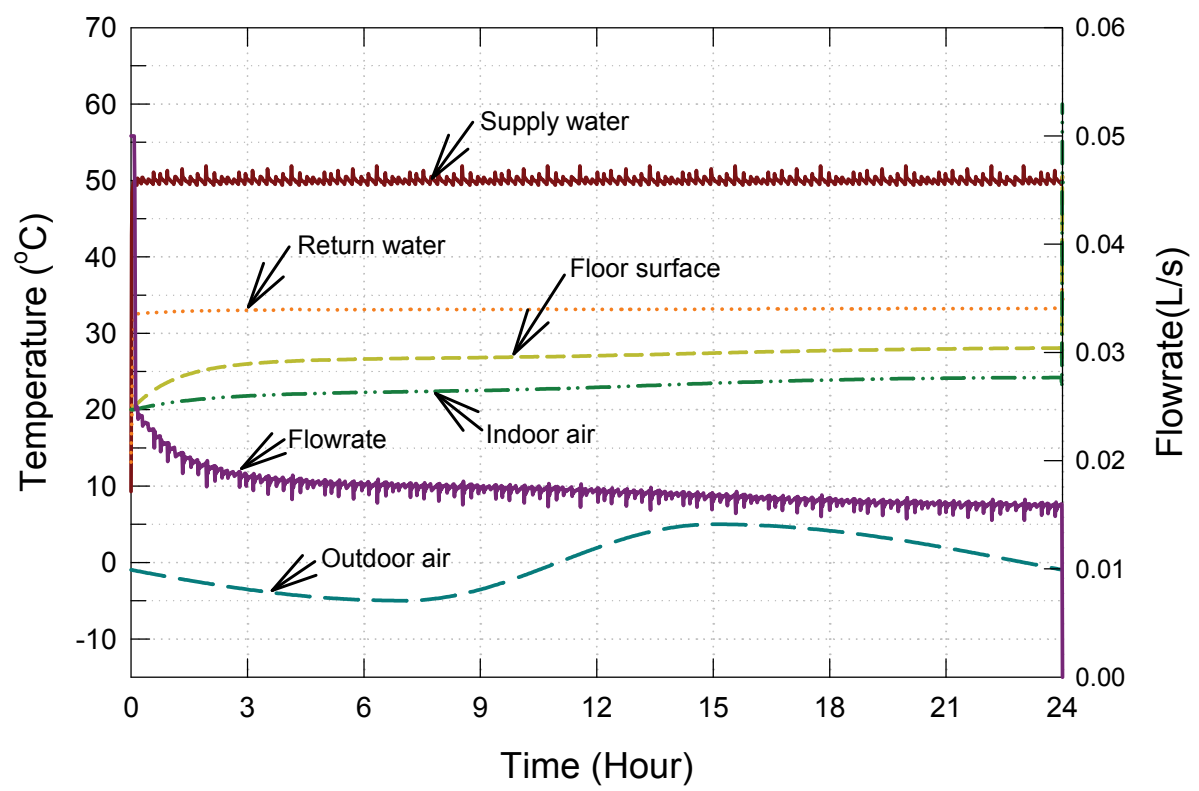

Fig. 12. Various temperature responses with proportional valve control with return water temperature feedback (Case 3)

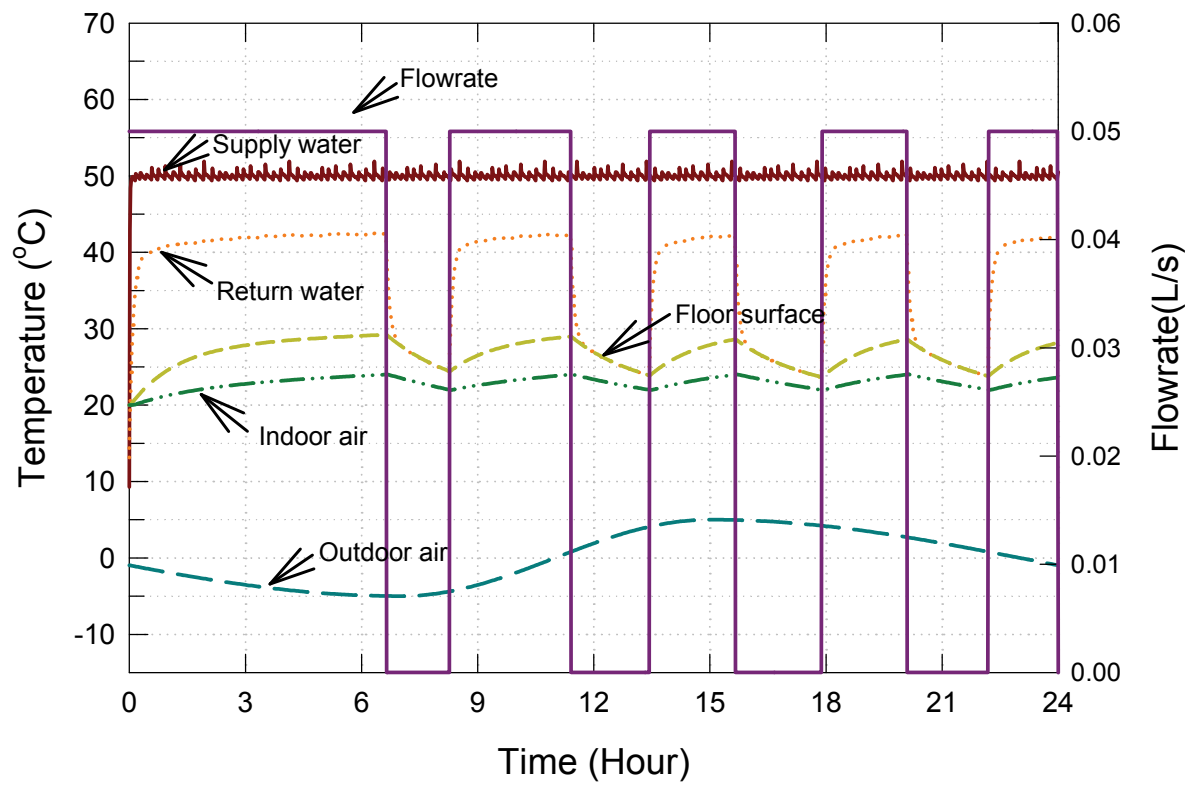

Fig. 13. Various temperature responses with on-off valve control with air temperature feedback (Case 4) 
Fig. 13 shows changes to temperature and flow rate for 24 hours in flow-rate supply on-off at a range of indoor air temperatures (Case 4$), 22.3^{\circ} \mathrm{C}$ to $23.5^{\circ} \mathrm{C}$.

The operation time is long due to the set point of indoor temperature of $20^{\circ} \mathrm{C}$, and then shortens due to intervals of $1^{\circ} \mathrm{C}$ of On-Off. The process is more time consuming when the outdoor temperature is lower and the relatively non-operational time shortens. The indoor air temperature vibrates from $22.5^{\circ} \mathrm{C}$ to $23.5^{\circ} \mathrm{C}$ according to the control, and the return water temperature almost reduces to the floor temperature when the flow supply is stopped. At this time, the mean temperatures of return water and indoor air are $34.4^{\circ} \mathrm{C}$ and $22.8^{\circ} \mathrm{C}$, respectively.

For the On-Off control, time differences are created between the hot water supply and nonsupply as the outdoor air temperature changes, and the indoor air temperature affects the control. But the control does not maintain the indoor air and creates a fluctuation in temperature. It is therefore important to set the proper point and use a differential gap.

Fig. 14 shows the mean temperature of the room air and total amount of heat supply according to controls. No-Control (Case 1) is $2^{\circ} \mathrm{C}$ and $14,000 \mathrm{Kcal}$ higher than other controls (Case 2 4). All controls, Cases 2 4, have a similar mean temperature but the water temperature-sensing control (Case 3 ) uses about $8 \%$ more heat than the air temperature sensing control (Case 2, Case 4).

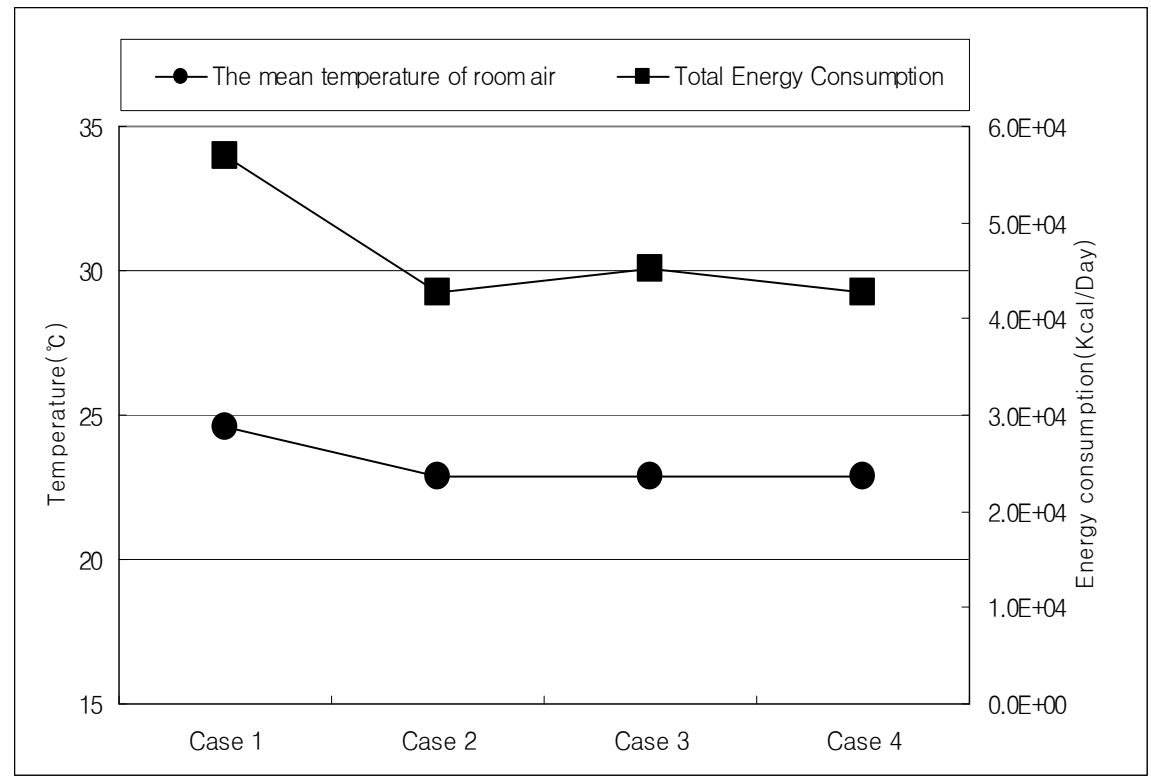

Fig. 14. Mean temperature of indoor air and total energy consumptions with different control methods (supply water temperature of $50^{\circ} \mathrm{C}$ )

Control variables of radiant floor heating system can usually be considered as supply hot water temperature and set value of indoor temperature. These control variables must be set to a proper value to improve indoor thermal environment and save energy, and variable values reflecting amount of outdoor temperature can be considered. 


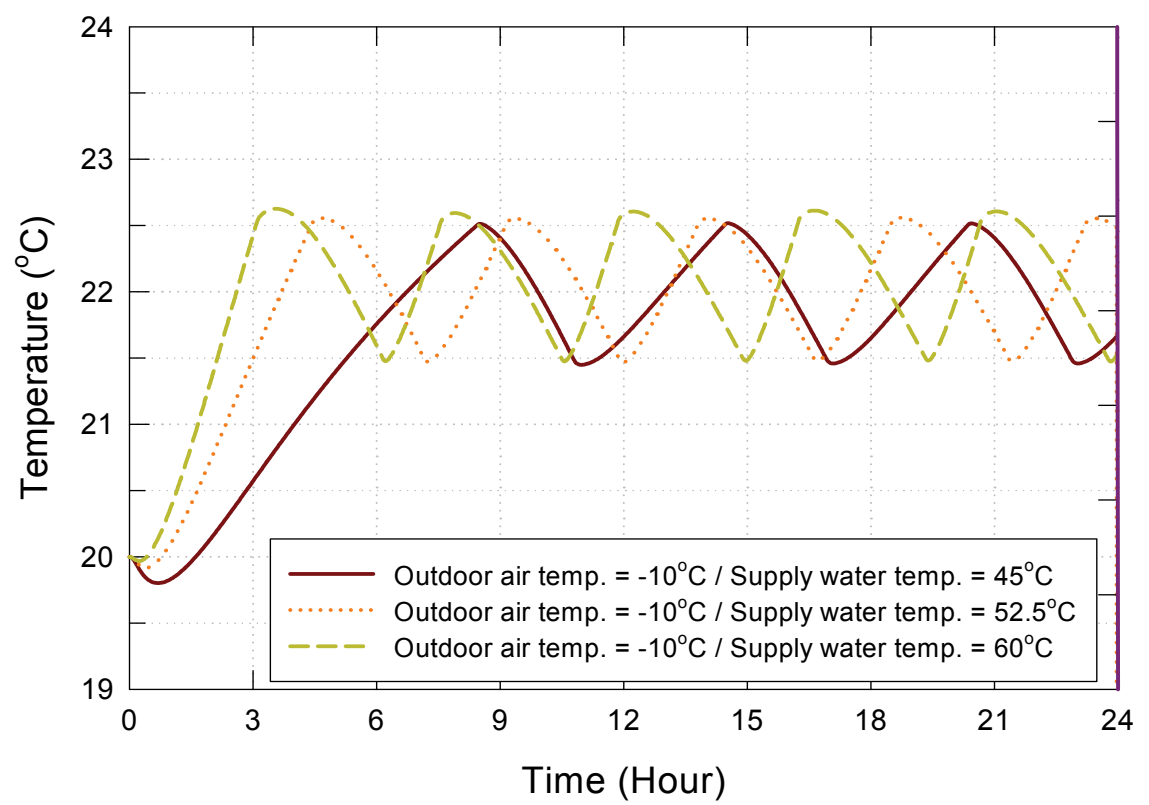

Fig. 15. Indoor air temperature responses for various supply water temperatures

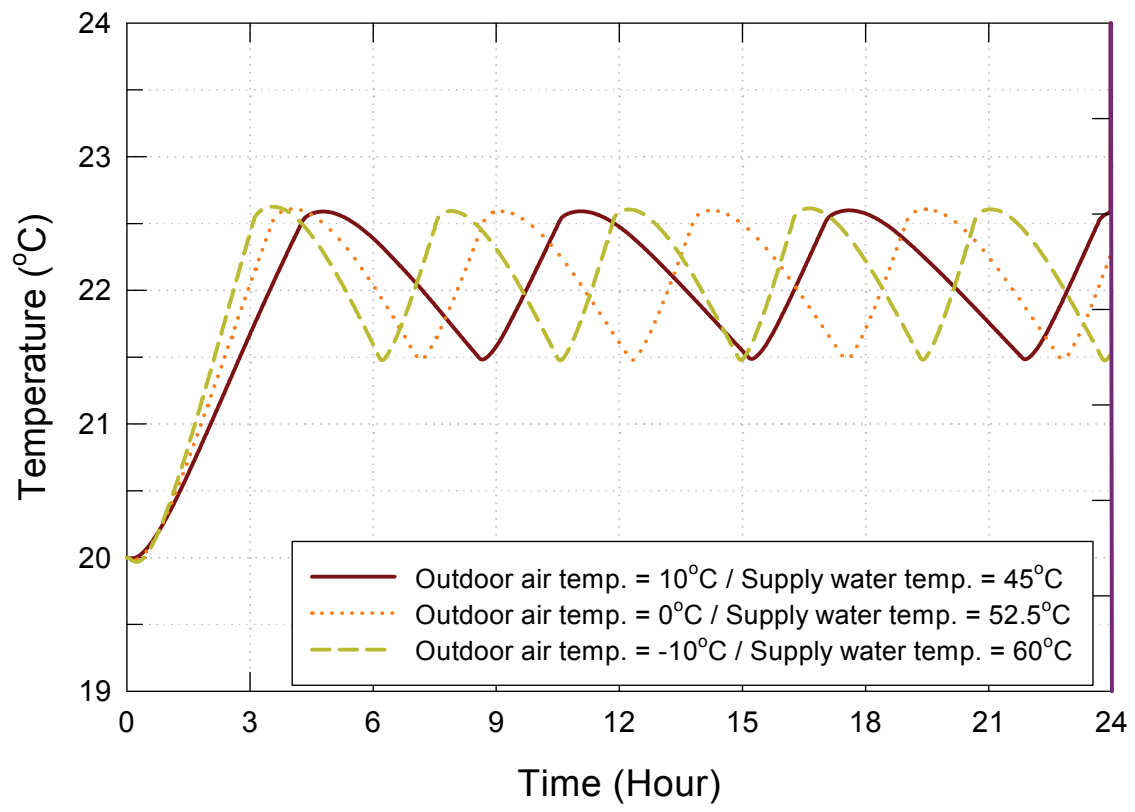

Fig. 16. Indoor air temperature responses for various supply water and outdoor air temperatures 
First of all, Fig. 15 shows characteristics of indoor air temperature alternation when supply hot water temperature is $45^{\circ} \mathrm{C}, 52.5^{\circ} \mathrm{C}, 60^{\circ} \mathrm{C}$ in case of setting outdoor temperature condition as $-10^{\circ} \mathrm{C}$. The control method here is the result of applying on-off control method (the on-off for the supply water by the differential gap according to the difference between the room temperature and setting point), using indoor air temperature sensor.

The diagram indicates that the time to reach the setting point $22^{\circ} \mathrm{C}$ is radically increasing when using relatively low temperature supply water in case of decreasing outdoor temperature. Analyzing from the data that more than 6 hours is needed for supply hot water temperature at $45^{\circ} \mathrm{C}$ to reach $22^{\circ} \mathrm{C}$, considerable amount of time is consumed in order to improve indoor thermal environment to a comfortable range in case when outdoor temperature is low and low temperature supply water is provided. Thus, relatively warmer hot water than cooler hot water is appropriate for heating in case of low outdoor temperature (Ahn, 2005).

Fig. 16 shows dynamic characteristics of indoor air temperature change when supply water temperature is $60^{\circ} \mathrm{C}, 52.5^{\circ} \mathrm{C}$, and $45^{\circ} \mathrm{C}$ at outdoor temperature condition of $-10^{\circ} \mathrm{C}, 0^{\circ} \mathrm{C}$, and $10^{\circ} \mathrm{C}$. Overshoot of each 3 separate cases depicted similar amount on indoor air temperature change, and the rise times to reach the set indoor air temperature $22^{\circ} \mathrm{C}$ were close to 3 hours without difference. By correctly determining supply hot water temperature in regard to amount of outdoor temperature, transient response characteristics for indoor environment can be improved.

Fig. 17 depicts characteristics of energy consumption and indoor air temperature average considering temperature alternation of outdoor and supply hot water.

Energy consumption and indoor air temperature average entirely rises as temperature of supply hot water or outdoor increases on the graph. The energy consumption gap was moderate in terms of supply hot water temperature change, while it was relatively large for outdoor temperature change. Therefore, changing supply hot water temperature in terms of outdoor temperature variation will minimize overheating and benefit energy savings.

Furthermore, if high temperature hot water were provided to make indoor air temperature reach its set temperature, supplying time of hot water would be lessened due to rapid increase of indoor air temperature despite of large consumption of heat amount depending on temperature difference. On the other hand, when low temperature hot water is provided, heat amount consumption will decrease, but supplying time will be delayed due to slow increase rate of indoor air temperature so that amount difference of energy consumption will be small.

Fig. 18 depicts result measured from the experiment about flow rate change characteristics and temperature change of radiant floor heating system. This is to demonstrate general thermal change features of radiant floor heating system from each boiler-installed household that is run by individual heating method.

Fig. 18 indicates temperatures of supply water, returning water, floor surface, indoor air, outdoor air, and flow rate. Temperature of supply water from supply header was at maximum $50^{\circ} \mathrm{C}$ due to heat loss from pipe, while it is being operated as on-off type control by boiler system.

Therefore, heat loss must be considered when determining set value of the supply water temperature. In addition, while indoor air temperature is being controlled up to $23 \pm 0.5^{\circ} \mathrm{C}$ by 


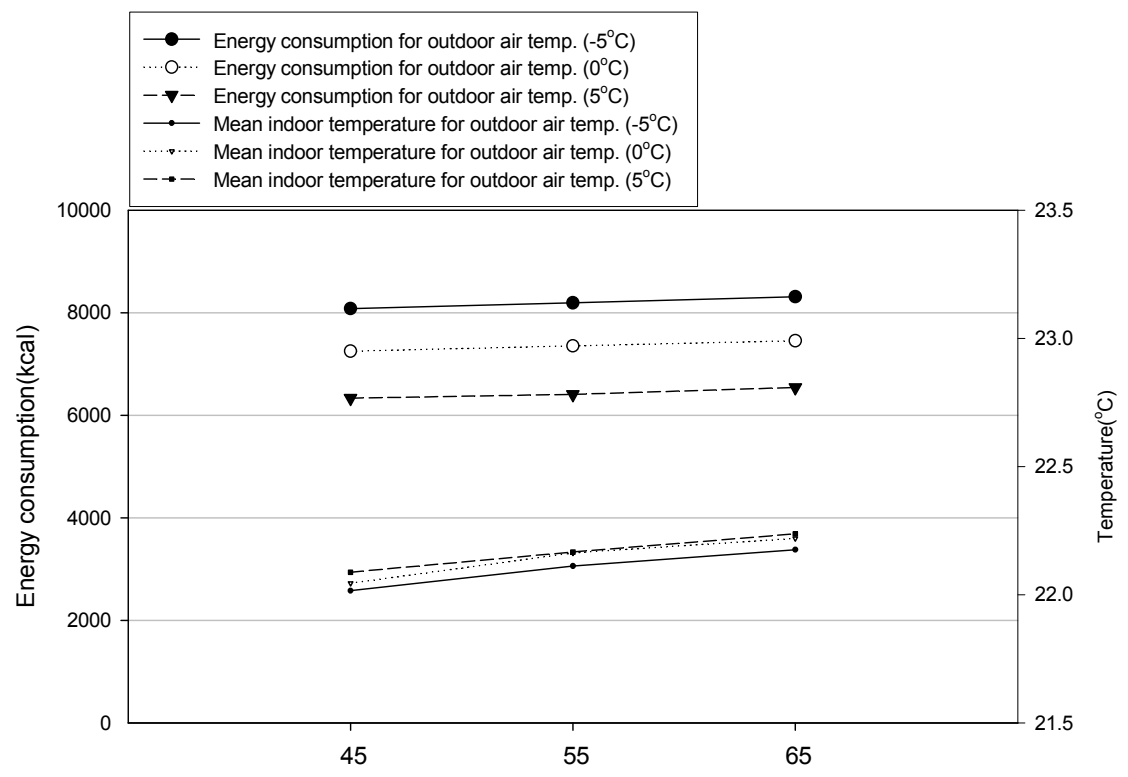

Supply water temperature $\left({ }^{\circ} \mathrm{C}\right)$

Fig. 17. Energy consumption and mean indoor air temperature responses for various supply water and outdoor air temperatures

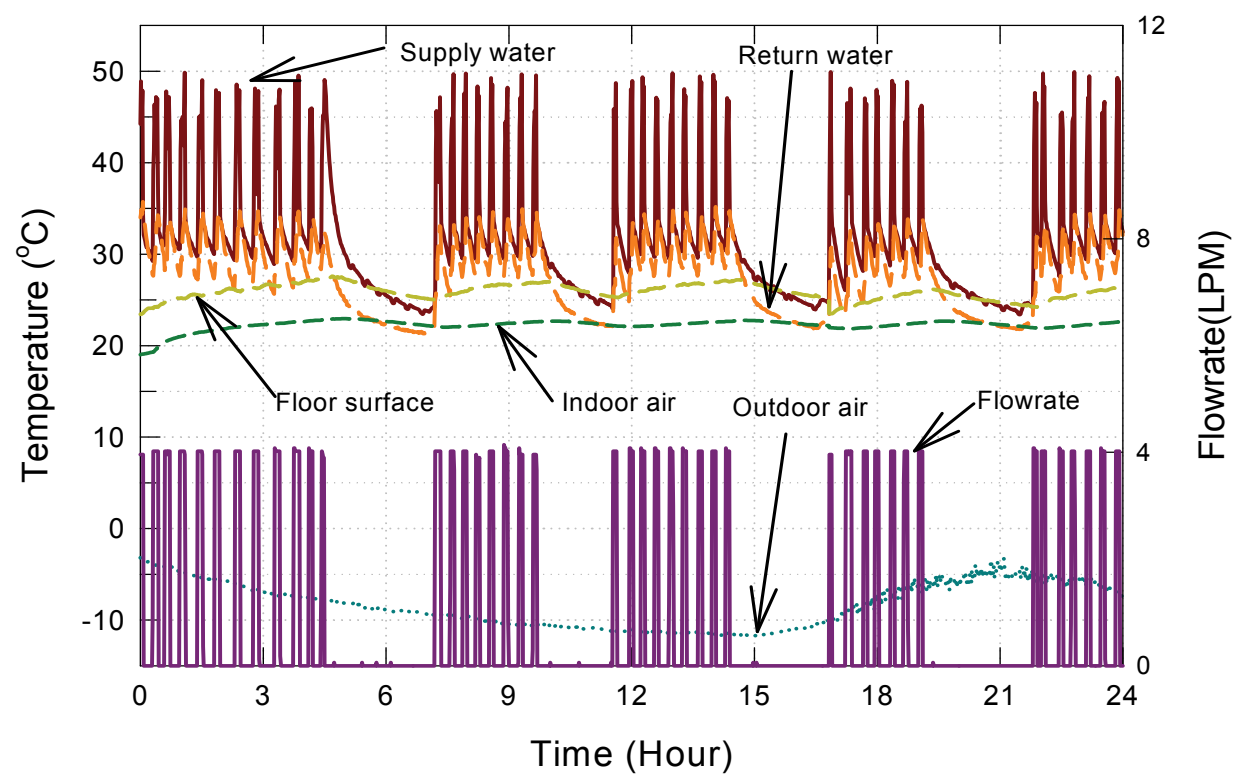

Fig. 18. Experimental results for the response characteristics of temperature and flow rate 
on-off type, initial operation time period to reach set indoor temperature is relatively slower than that of after second period, and temperature alternation of indoor air and floor surface seems severely slow even after hot water is being supplied. Thus, thermal environment would be improved if indoor air temperature increasing period were reduced by initially supplying comparably hotter water temperature, and cooling it down afterwards.

\section{Conclusions}

Radiant floor heating system is mainly applied to residential buildings. Recent trend shows increasing rate of countries applying the system to their residential buildings after considering various profits of the system.

However, the radiant floor heating system may contain long time delay as inappropriate response characteristics on indoor temperature control due to significant influence of thermal inertia when performing indoor air temperature control.

In order to improve thermal environment and save energy by effectively controlling the indoor air temperature, temperature value of supply hot water from boiler and indoor air set temperature can be altered by forecasting the value of outdoor temperature and characteristics variation.

Therefore, application of more effective system design and advanced control technique for radiant floor heating system like HVAC system(Ahn, 2001) is required through consistent technology research and development.

\section{References}

Ahn, B.C. and Mitchell, J.W. (2001). Optimal Control Development for Chilled Water Plants using a Quadratic Representation, Energy and Buildings 33, pp.371-378, Elsevier, ISSN 0378-7788

Ahn. B.C. and Lee, T.W. (2005). Strategy of Energy Saving and Thermal Environmental Improvement for Intermittent Heating System in Apartment Buildings, Journal of the SAREK, Vol.17, pp.88-93, ISSN 1229-6422

Ahn, B.C. and Song, J.Y. (2010). Control Characteristics and Heating Performance Analysis of Automatic Thermostatic Valves for Radiant Slab Heating System in Residential Apartment, Energy 35, pp.1615-1624, Elsevier, ISSN 0360-5442

ASHRAE Handbook, HVAC Systems and Equipment. (2004). Panael Heating and Cooling, Chapter 6, 6.1-6.22. ISBN 1-931862-48-6, Atlanta, USA

Chang, H.W. and Ahn, B.C. (1996). The Energy Analysis and Control Characteristics of a Ho Water Heating System for Apartment Houses, Journal of the SAREK, Vol.8, pp.76-87, ISSN 1229-6422

Holman, H.J. (1981). Heat Transfer, 5th Ed., McGraw-Hill. , ISBN 0-07-029618-9, MI, USA

Segel Robert and Howell, J.R. (1981). Thermal Radiation Heat Transfer, McGraw-Hill. , ISBN 0-07-057316-6, New York, USA

Sepsy, C.F. (1972). A Thermal Analysis of the Building and the Heating and Cooling Systems Selected for the Field Validation Test, ASHRAE Sym. Bulletine No. 72, pp.59. 
Stoecker, W.F. (1980). Design of Thermal Systems, McGraw-Hill, ISBN 0-07-061618-3, Tokyo, Japan 


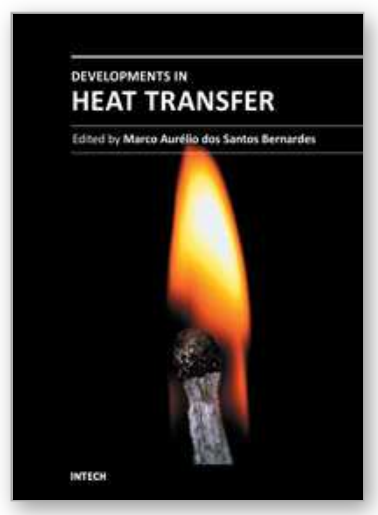

\author{
Developments in Heat Transfer \\ Edited by Dr. Marco Aurelio Dos Santos Bernardes
}

ISBN 978-953-307-569-3

Hard cover, 688 pages

Publisher InTech

Published online 15, September, 2011

Published in print edition September, 2011

This book comprises heat transfer fundamental concepts and modes (specifically conduction, convection and radiation), bioheat, entransy theory development, micro heat transfer, high temperature applications, turbulent shear flows, mass transfer, heat pipes, design optimization, medical therapies, fiber-optics, heat transfer in surfactant solutions, landmine detection, heat exchangers, radiant floor, packed bed thermal storage systems, inverse space marching method, heat transfer in short slot ducts, freezing an drying mechanisms, variable property effects in heat transfer, heat transfer in electronics and process industries, fission-track thermochronology, combustion, heat transfer in liquid metal flows, human comfort in underground mining, heat transfer on electrical discharge machining and mixing convection. The experimental and theoretical investigations, assessment and enhancement techniques illustrated here aspire to be useful for many researchers, scientists, engineers and graduate students.

\title{
How to reference
}

In order to correctly reference this scholarly work, feel free to copy and paste the following:

Byung-Cheon Ahn (2011). Radiant Floor Heating System, Developments in Heat Transfer, Dr. Marco Aurelio Dos Santos Bernardes (Ed.), ISBN: 978-953-307-569-3, InTech, Available from:

http://www.intechopen.com/books/developments-in-heat-transfer/radiant-floor-heating-system

\section{INTECH}

open science | open minds

\author{
InTech Europe \\ University Campus STeP Ri \\ Slavka Krautzeka 83/A \\ 51000 Rijeka, Croatia \\ Phone: +385 (51) 770447 \\ Fax: +385 (51) 686166 \\ www.intechopen.com
}

\author{
InTech China \\ Unit 405, Office Block, Hotel Equatorial Shanghai \\ No.65, Yan An Road (West), Shanghai, 200040, China \\ 中国上海市延安西路65号上海国际贵都大饭店办公楼 405 单元 \\ Phone: +86-21-62489820 \\ Fax: +86-21-62489821
}


(C) 2011 The Author(s). Licensee IntechOpen. This chapter is distributed under the terms of the Creative Commons Attribution-NonCommercialShareAlike-3.0 License, which permits use, distribution and reproduction for non-commercial purposes, provided the original is properly cited and derivative works building on this content are distributed under the same license. 